
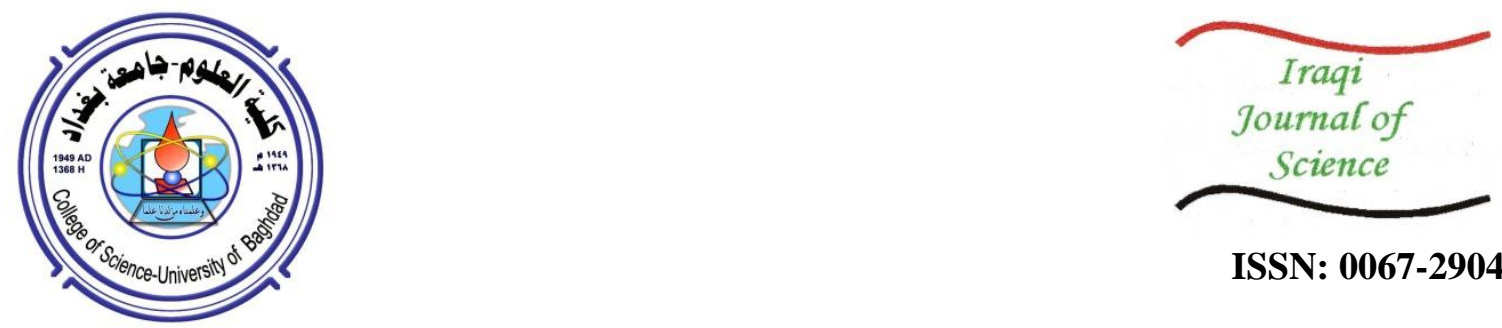

ISSN: 0067-2904

\title{
Surface Basins Evaluation of the Southern Desert, West Iraq
}

\author{
Ali Hussein Ali*, Kamal K. Ali , Ayser M. Al-Shamma'a \\ Department of Geology, College of Science, University of Baghdad, Baghdad, Iraq
}

Received: 16/4/2020 Accepted: 26/12/2020

\begin{abstract}
The results of the present study show that the highest elevation point is (912) meters (a.s.1.) inside Wadi Al-Khur basin while the lowest elevation point is (6) meters (a.s.1.) inside Wadi Abu-Talha basin. The biggest catchment area is represented by Wadi Al-Khur $\left(48840 \mathrm{~km}^{2}\right)$ whereas the smallest catchment area is Wadi Taqtaq $\left(1748 \mathrm{~km}^{2}\right)$. The stream direction of all streams trends from SouthWest towards North-East. The soil available water capacity (AWC) (Moisture Deficit) in the studied area was $15 \mathrm{~mm}$. The average annual rainfall was $133.11 \mathrm{~mm}$, the average annual temperature was $25.65 \mathrm{C}^{\mathrm{o}}$, the total depth amount of $\mathrm{E}$ Apanwas $3691.85 \mathrm{~mm} /$ year, the relative humidity was $40 \%$, the average annual sunshine is $7.9 \mathrm{hrs}$., and the average annual wind speed is $2.7 \mathrm{~m} / \mathrm{s}$. The water surplus of the total studied area $46800 \mathrm{~km}$ ) was about $488.592 \mathrm{~m}^{3} / \mathrm{year}$, while the runoff amount was about $442.190 \mathrm{~m}^{3}$ year.
\end{abstract}

Keywords: Hydrological condition, GIS, DEM, Top soil, Water surplus.

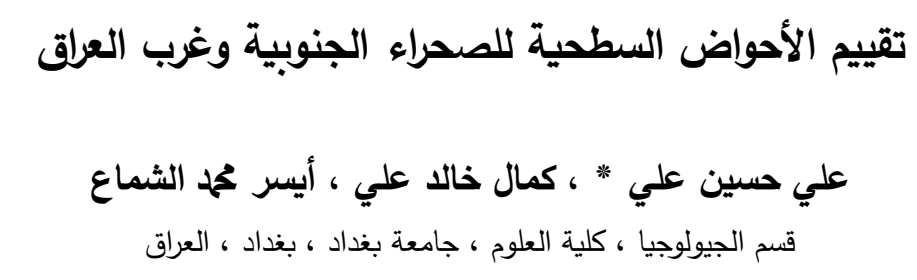

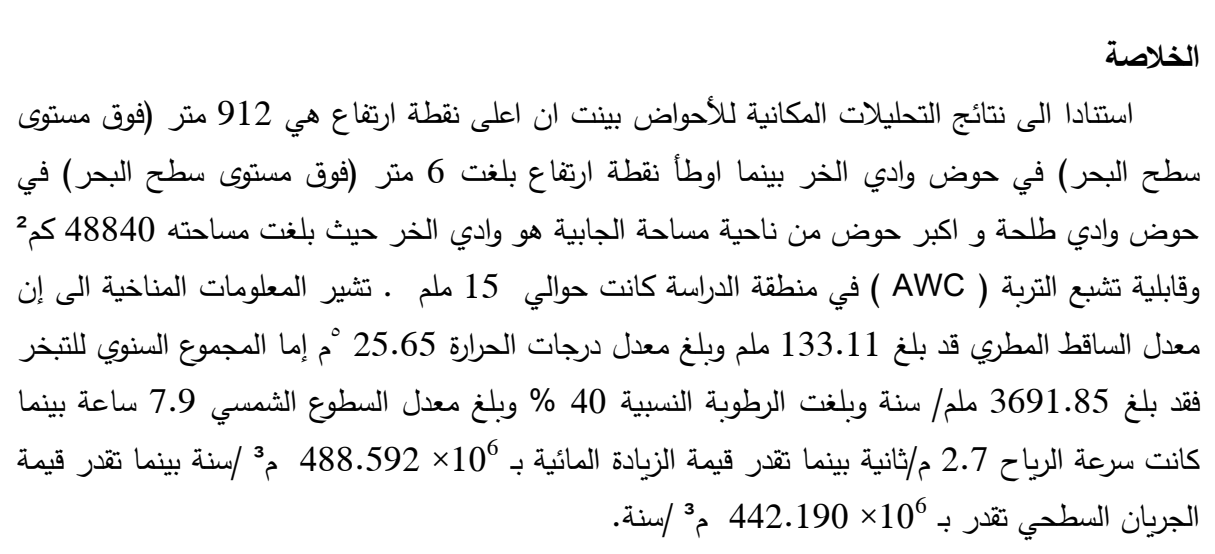

\section{Introduction}

The studied area is located within the Iraqi western desert, where the geographic coordinates are the longitudes of $43^{\circ} 00^{\prime}-46^{\circ} 13^{\prime}$ East and the latitudes of $29^{\circ} 09^{\prime}-32^{\circ} 01^{\prime}$ North, with a total area of about $46800 \mathrm{~km}^{2}$. It is located along the Southern Desert, specifically within Salman subzone in the stable shelf (according to the Iraq tectonic divisions). In this area, the Lower-Middle Eocene strata 
outcrop in the west and the Lower and the Middle Miocene beds outcrop in the east [1]. The global climate change is expected to change the parameters of the hydrometeorological processes. Thus, according to the climate classifications, the climate of the study area is described as continental and dry [2]. Climate and hydrological conditions in any hydrological basin are a multi-combined reflection of natural factors of morphology and soil nature [3], as well as the changes in climate factors that affect directly the hydrological cycle. Water balance techniques are a main solution of important theoretical and practical hydrological problems [3]. This research objective is to calculate the water surplus and evaluate the hydrological conditions in the Dammam Formation within the southern desert.

\section{Methods}

\section{1- Calculating watershed in the studied area}

The advantages of hydrological analysis by using the digital elevation map of (DEM-27) meter resolution is that it has significant advantageous effects on the accuracy of the distribution model and the physics-based distribution models over the entire watershed in the studied area. The hydrological condition of the studied area's basins was defined through determining the physiographic properties of the area that is best representing the hydrological processes. The GIS technology was used to analyse parameters of spatial distribution of the catchment and numerical integration of the mass conservation to simulate the stream runoff process. The watershed was subdivided into relatively small sub-basins to drainage divided based on topography. Routing reaches were identified and the overall order computation was defined for all related basins. The Arc-Hydro Tools extension was used to produce flow direction, flow accumulation, and stream grid. The triangulated irregular network (TIN) algorithm was used to create interpolation slope convergence for all basins.

The GIS program was used to preprocess the DEM and remove depression and flat areas without modifying other parts. Flow simulation algorithms were applied to determine the catchment area of each grid cell and the watershed boundary was defined to be analyzed. Channels tracing was directed by flow direction raster, leading to determine the length of each network link and the spatial coordinates of its upstream and downstream ends (Figure-1).

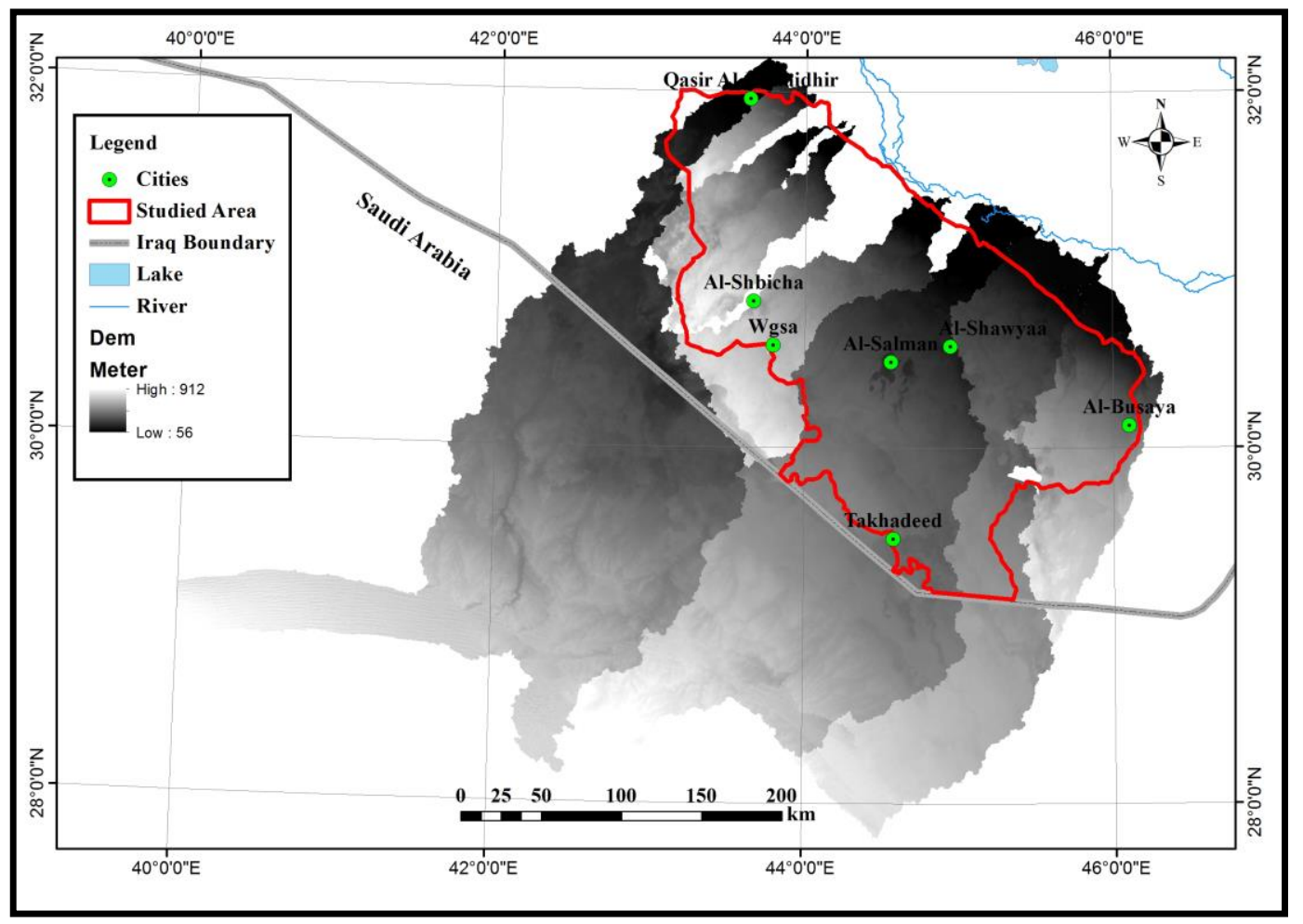

Figure 1- Watershed Image of the Studied Area

\section{2- Calculating the area of streams network}

The calculation of the studied area's watershed was based on outlet points which were divided into several surface sub-basins, while the main channel was plotted from elevation vs. horizontal distance, 
which is an indicator of the channel's gradient for each drainage basin. The small streams are joined together with large ones in the valleys to create more extensive ones. The direction of flow was determined by the direction of the steepest descent, or maximum drop, from each cell. The output raster was created, showing a ratio of the maximum change in elevation from each cell along the direction of flow to the path length between centers of cells. The flow direction of each Wadi was used to follow each link from its upstream end to its downstream end. Generally, the surface runoff is flowing towards north-east. The mean slope is high for most of the turbid streams, indicating the less amount of time required for water to move from the highest distant point of the watershed to the outlet stream. The velocity of the flowing water inside the stream is higher towards the lower point of the stream. Thus, less amount of water will be infiltrated to the groundwater aquifer as a recharge [4]. Figure -2 shows the distribution of the main surface basin in the studied area.

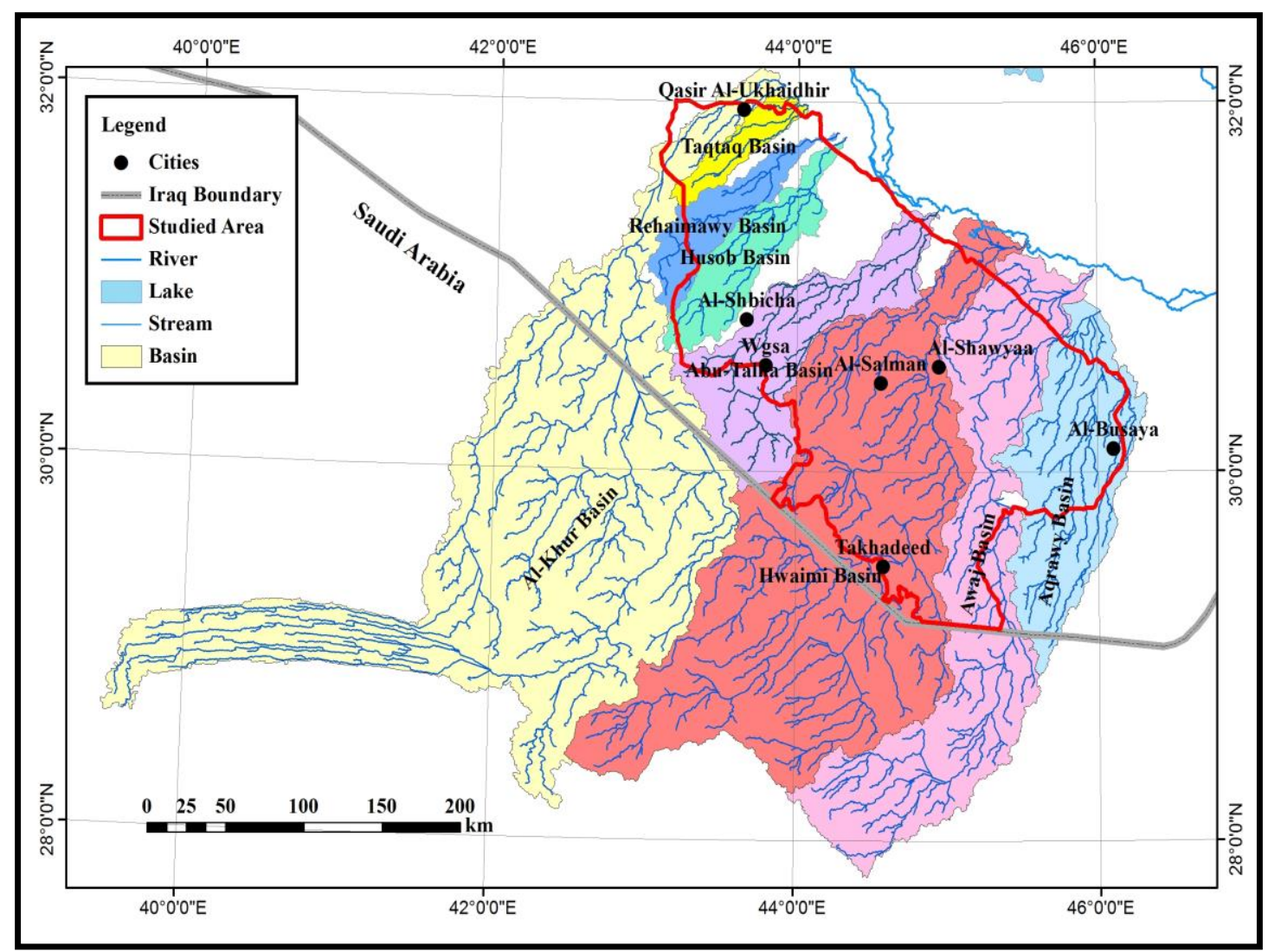

Figure 2- Main Surface Basin Distribution in the Studied Area.

The infiltrated recharge to the groundwater aquifers was related to the physiographic property of the basin. The drainage type depends on regional landforms and types of geological formations and soil materials [5].

According to previous studies [6,7], the expected ratio of runoff average ranges $2.5-3.86 \%$ of the yearly rain fall, through applying the soil conservation service (SCS) equation which allowed calculating the runoff for the watershed of the studied area.

The streams follow a branching drainage pattern called the dendritic pattern. Dendritic drainage patterns are irregular with tributaries at various angles from the main stream. The total studied area $\left(46800 \mathrm{~km}^{2}\right)$ was clipped and calculated to determine the 8 Wadi basins which were subdivided to two groups according to their distributions, as follows:

1- $\quad$ Local Basins: these basins are exposed along the studied area, including Wadi Taqtaq, Wadi Rhaimawy, Wadi Hussob, Wadi Abu-Talha, and Wadi Aqrawy (Figures- 3-7).

2- $\quad$ Transboundary Basins: these basins are distributed cross over the national boundary (IraqSaudi Arabia), including Wadi Al-Khur, Wadi Hwaimy and Wadi Awij (Figures- 8-10). 


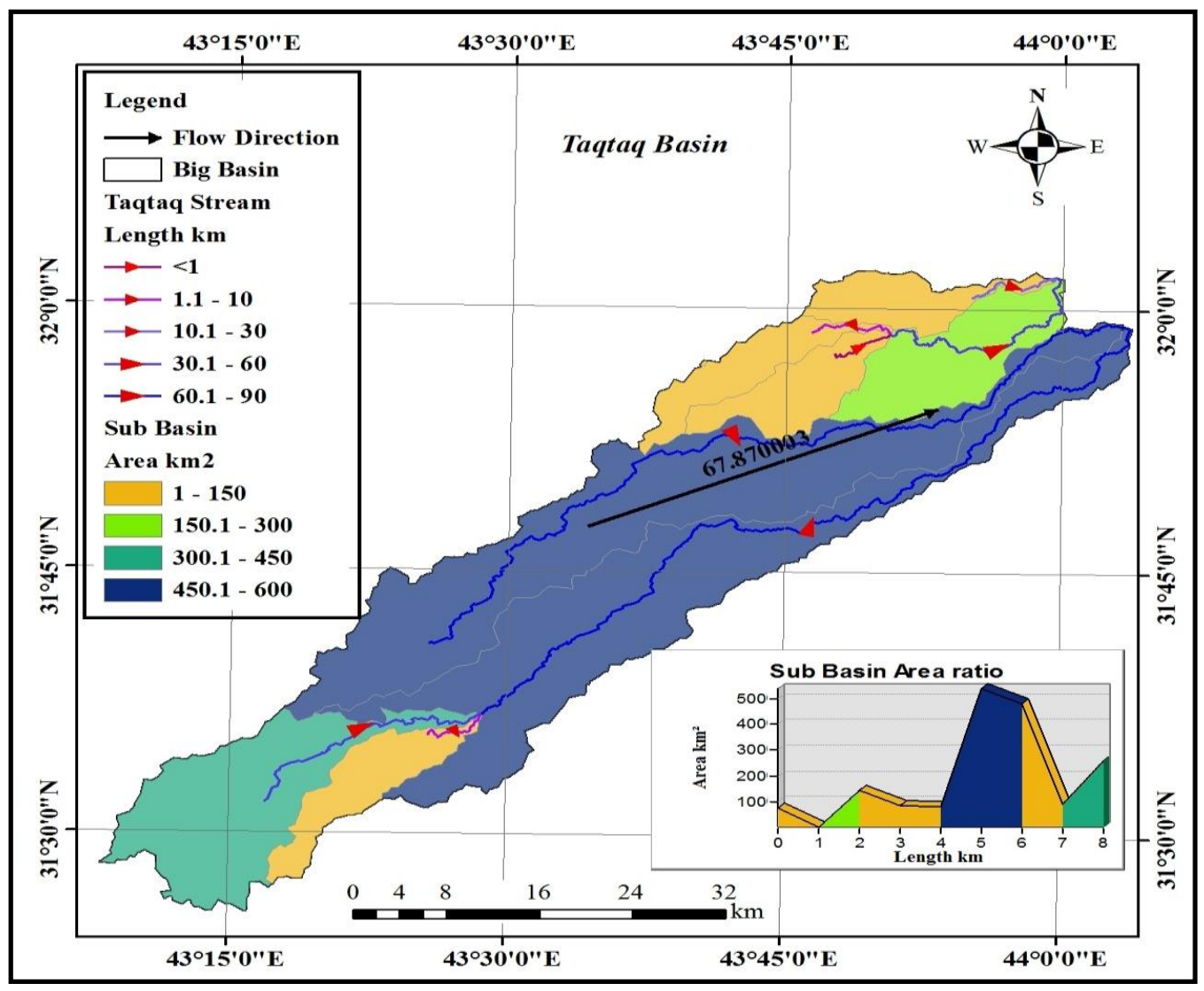

Figure 3- The sub-basin and flow direction of Wadi Taqtaq

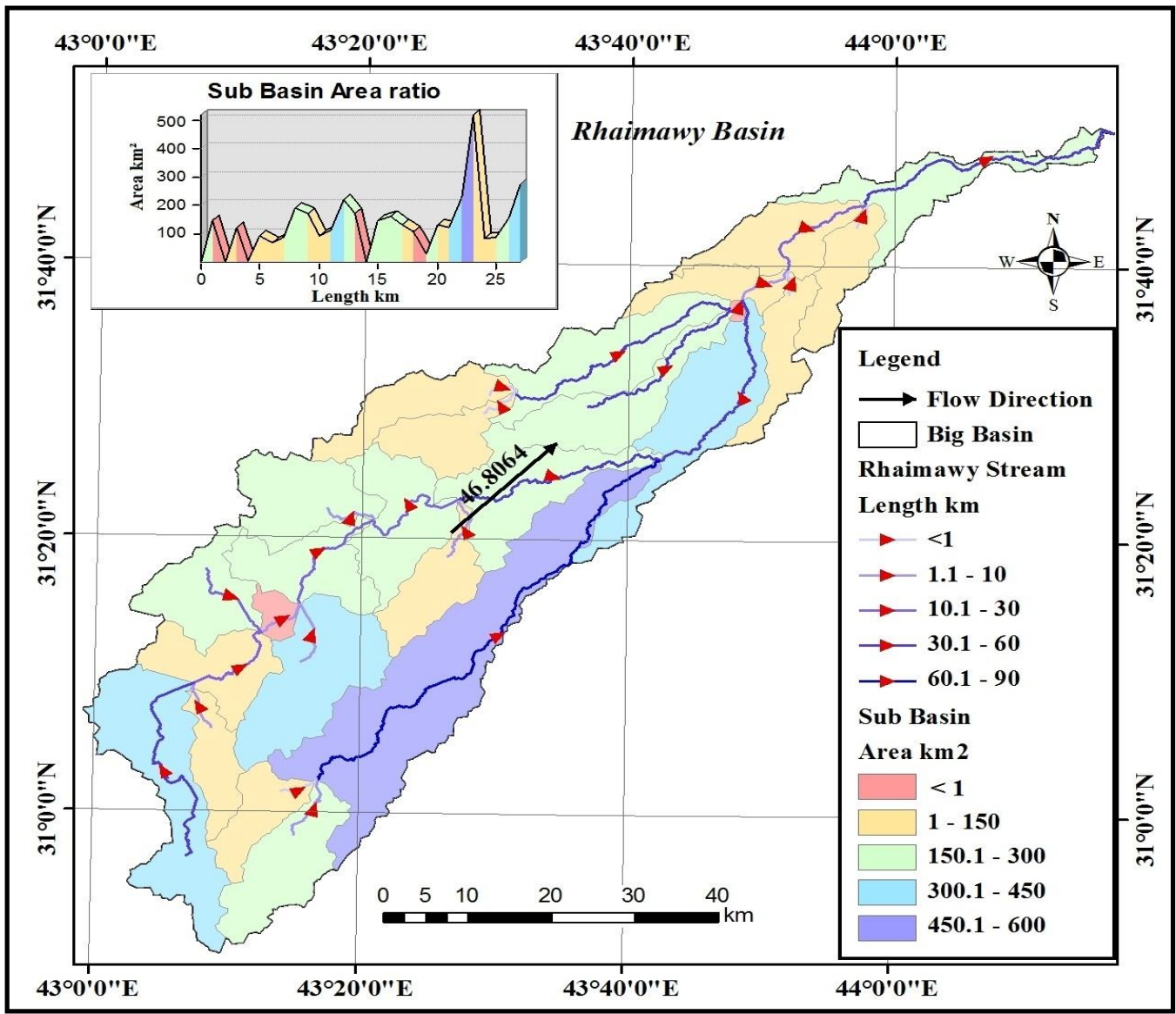

Figure 4- The sub-basin and flow direction of Wadi Rhaimawy. 


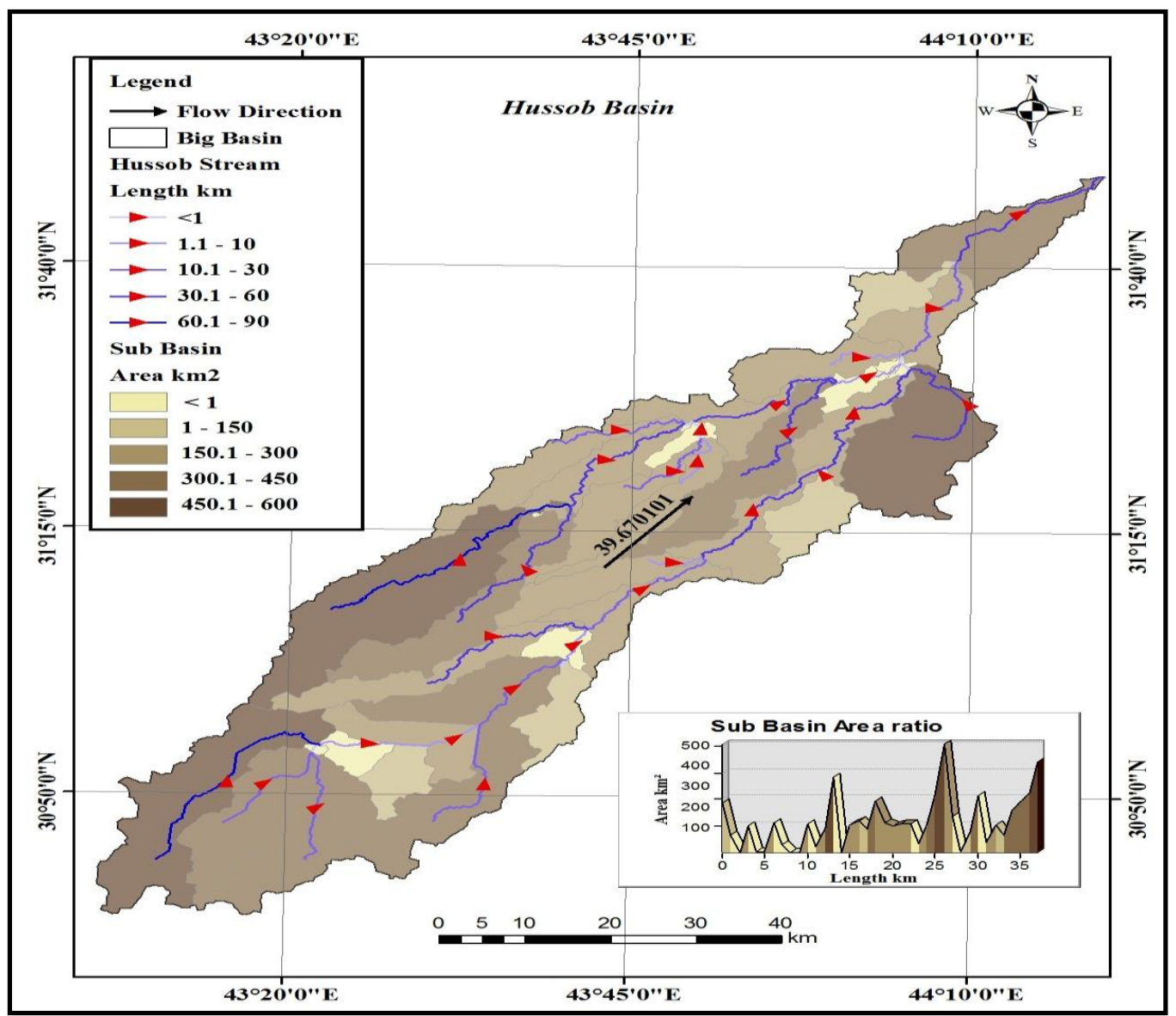

Figure 5- The sub-basin and flow direction of Wadi Hussob.

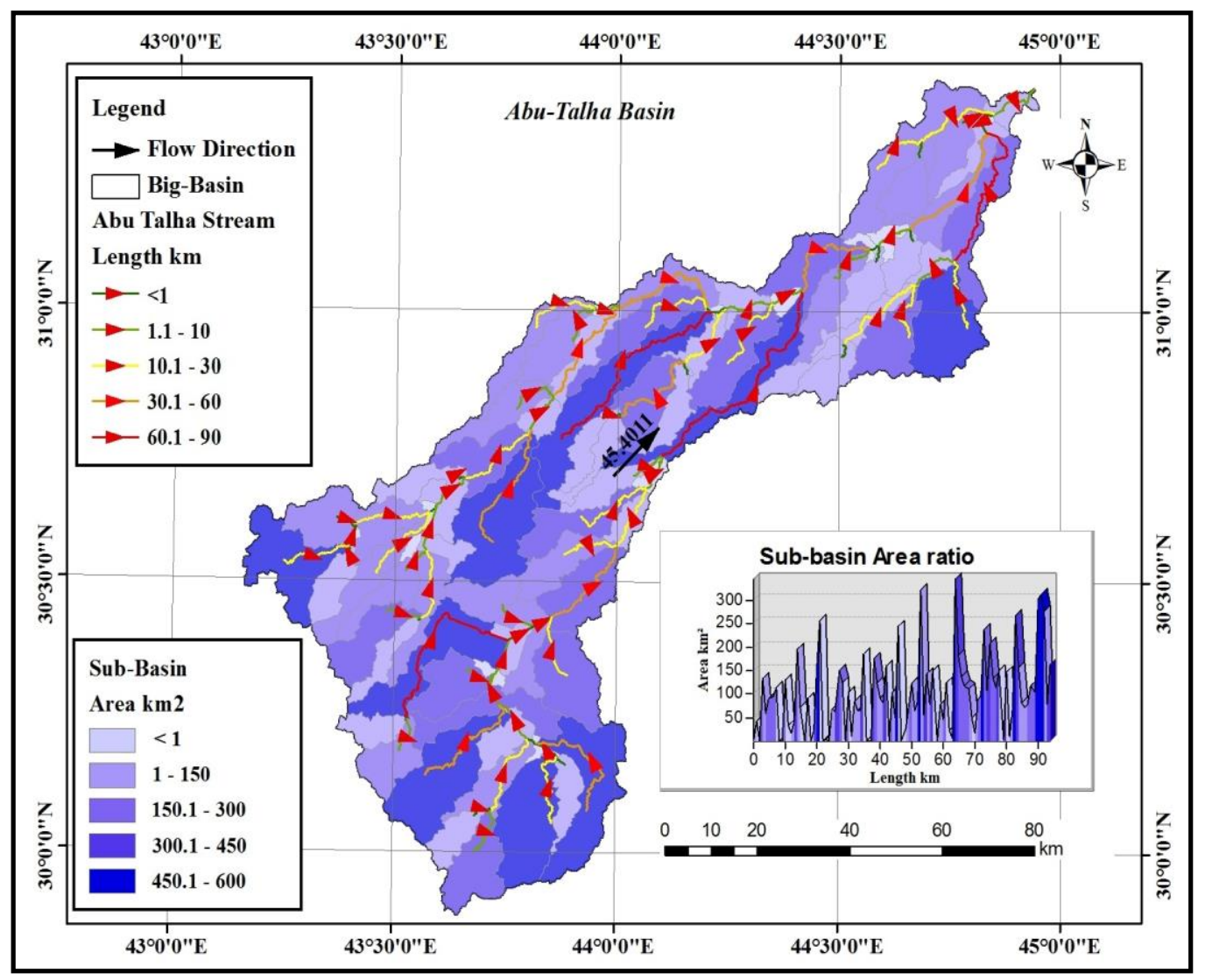

Figure 6- The sub-basin and flow direction of Wadi Abu-Talha. 


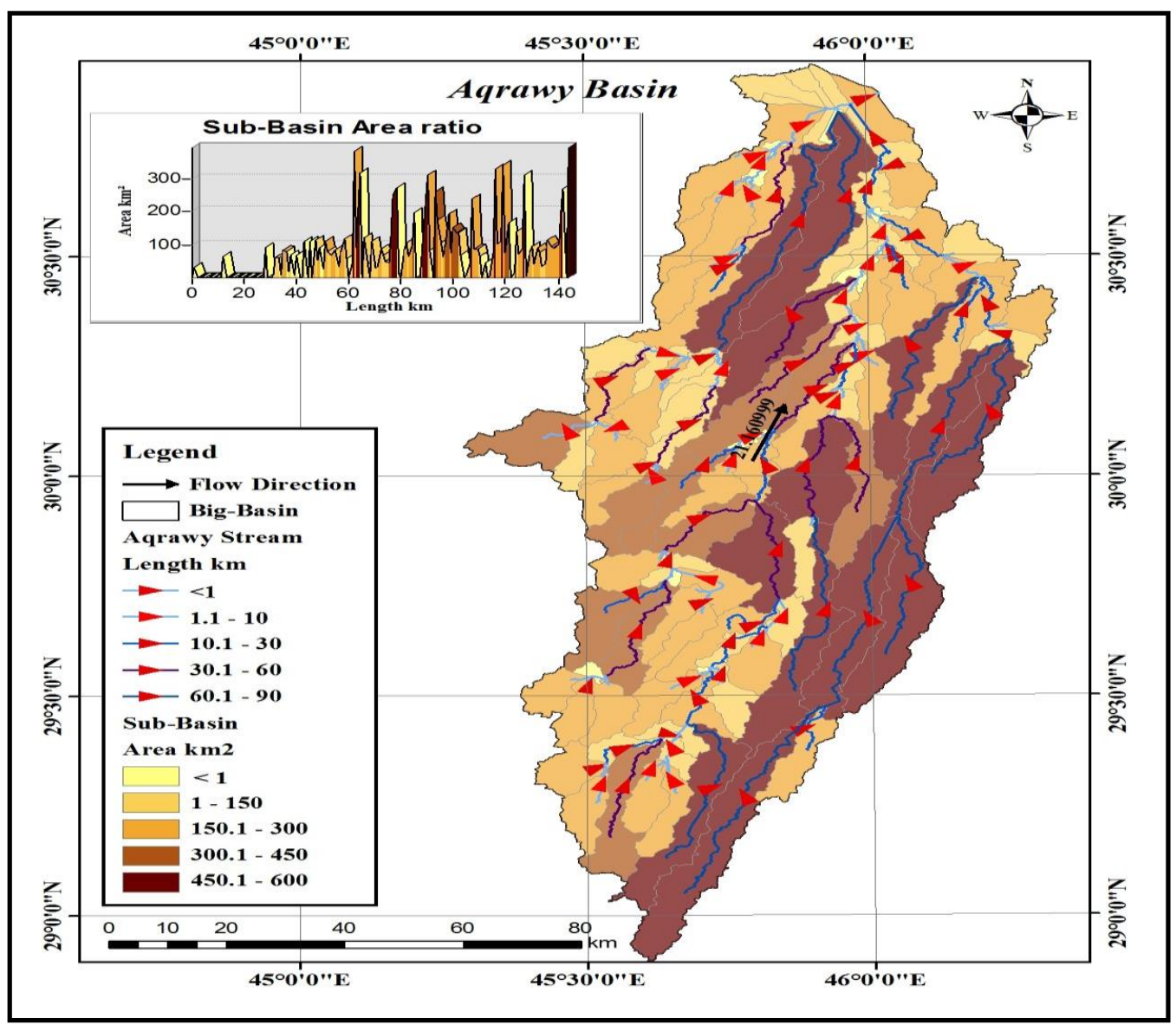

Figure 7- The sub-basin and flow direction of Wadi Aqrawy.

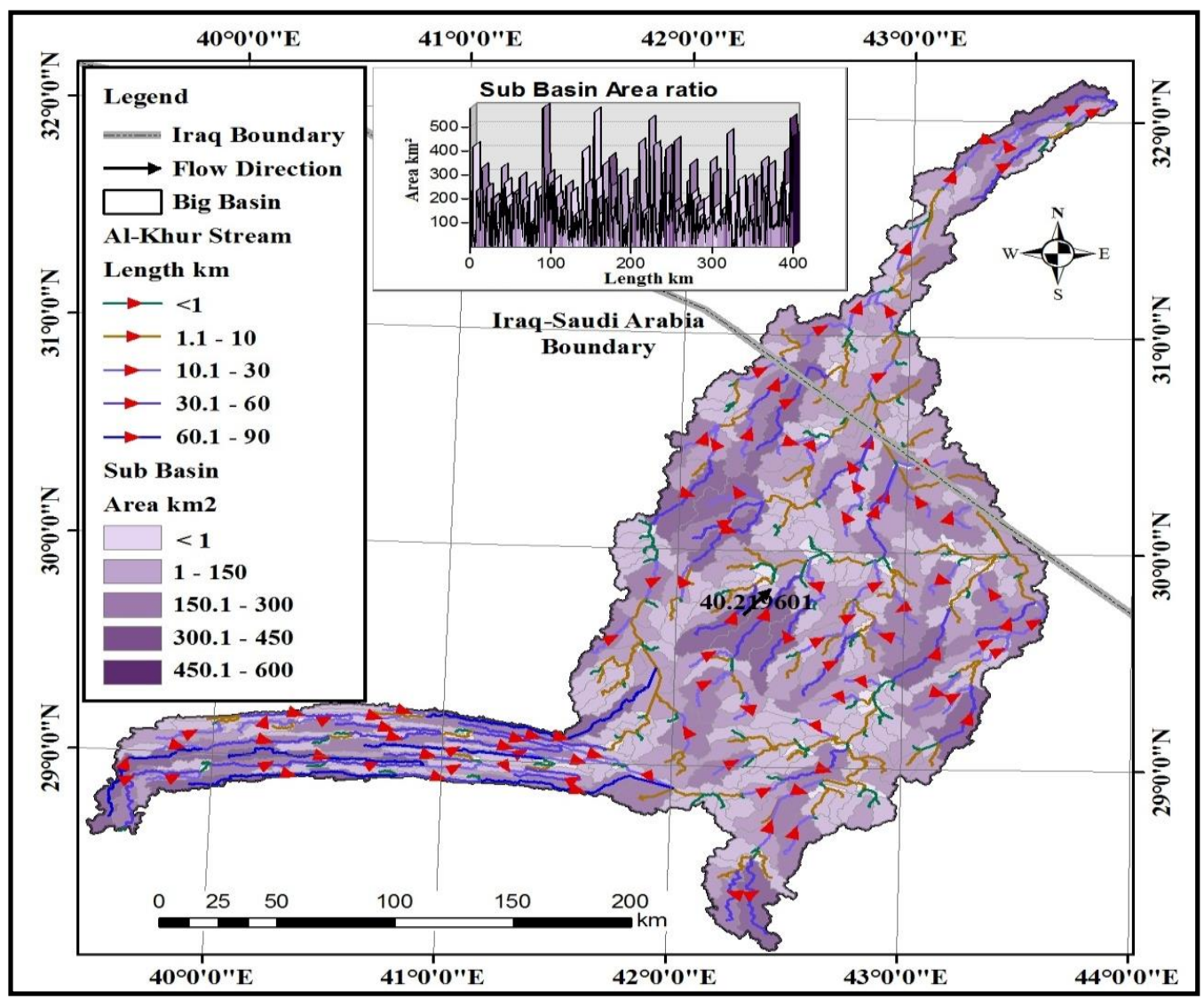

Figure 8- The sub-basin and flow direction of Wadi Al-Khur. 


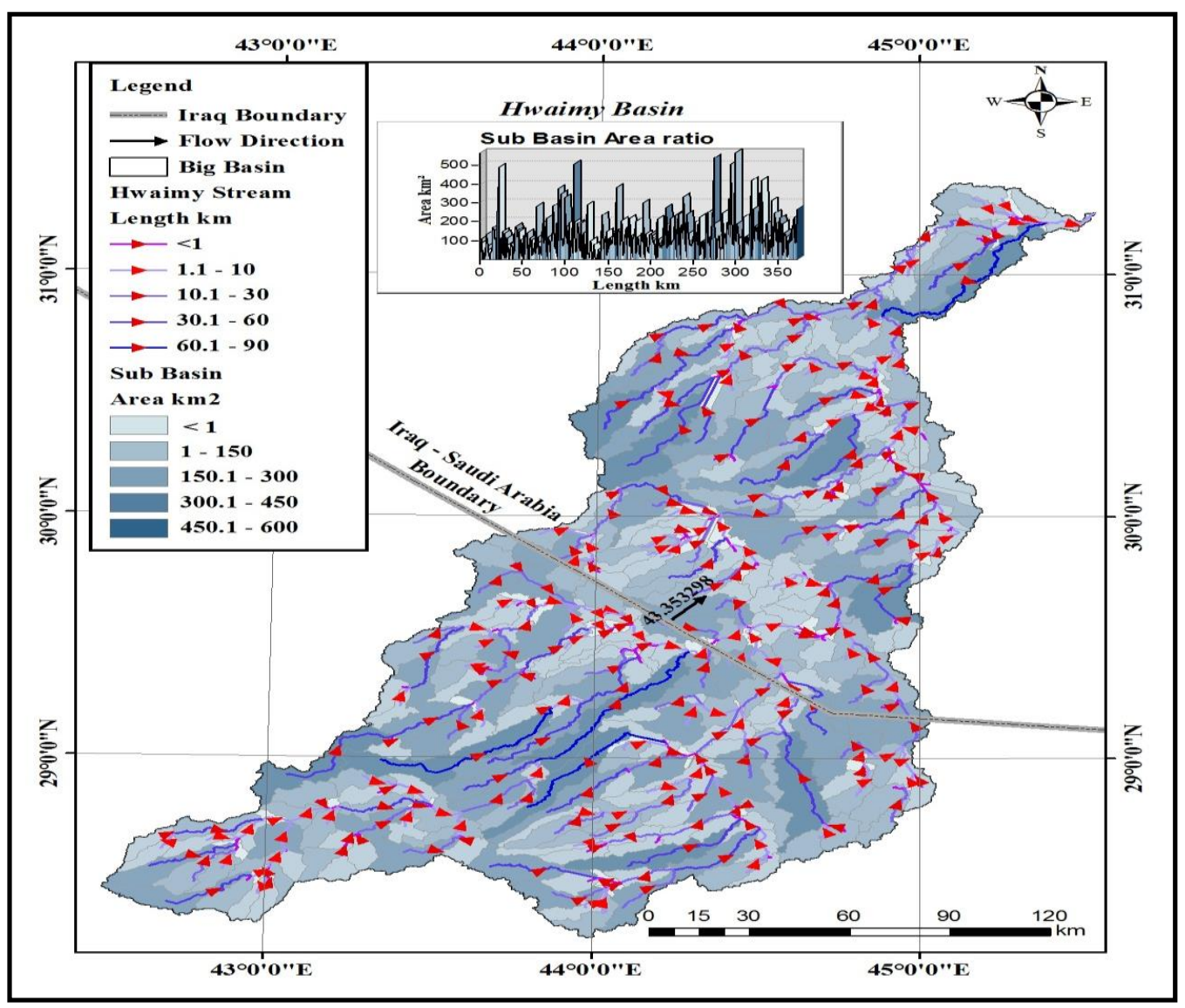

Figure 9- The sub-basin and flow direction of Wadi Hwaimy

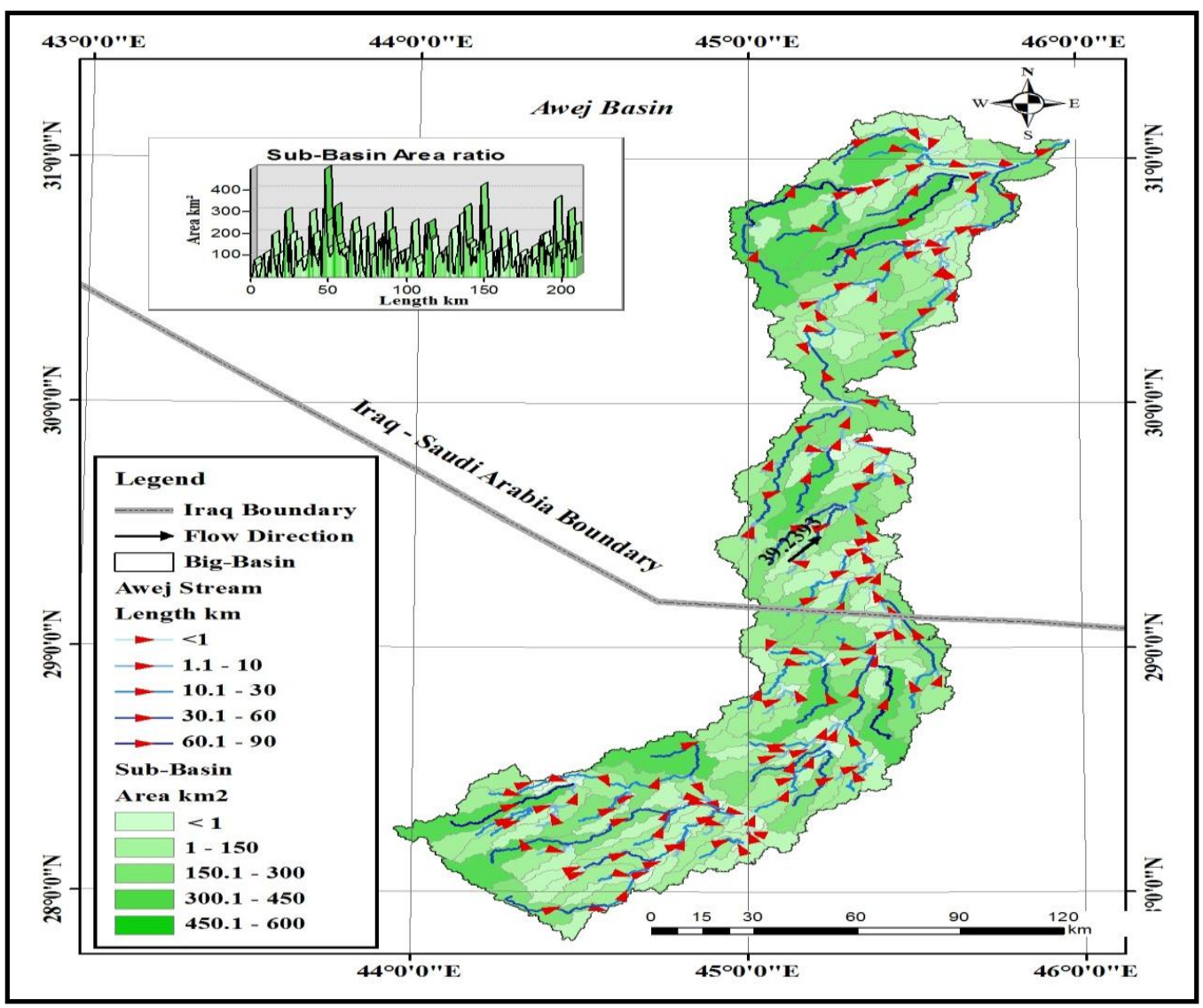

Figure 10- The sub-basin and flow direction of Wadi Awej 


\section{The Surface Basin Properties of the Studied Area}

The main surface basins in the studied area are generally big and most of tributaries flow from outside of the Iraqi territory, which provides the main stream with water. Accordingly, the calculated result of the basins considering the spatial analysis shows that the highest elevation point was $912 \mathrm{~m}$ (asl) inside Wadi Al-Khur basin, while the lowest elevation point was $6 \mathrm{~m}$ (asl) inside Wadi AbuTalha basin. The biggest catchment area is Wadi Al-Khur $\left(48840 \mathrm{~km}^{2}\right)$, whereas the smallest catchment area is Wadi Taqtaq $\left(1748 \mathrm{~km}^{2}\right)$. The stream direction of all streams trends from SouthWest towards North-East. The physiographic result demonstrated an effective watershed and an accurate hydrological simulation, which enabled water development projects to be accomplished such as construction of dams and groundwater recharges, (Table- 1).

Table 1- Physical Properties of the Wadis within the Studied Area

\begin{tabular}{|c|c|c|c|c|c|c|}
\hline No & Name & $\begin{array}{c}\text { Basin } \\
\text { Area } \\
(\mathrm{km} 2)\end{array}$ & $\begin{array}{c}\text { Stream Average } \\
\text { Length }(\mathrm{km})\end{array}$ & $\begin{array}{c}\text { Mean Direction } \\
\text { in Degree }\end{array}$ & $\begin{array}{c}\text { Highest } \\
\text { Elevation }(\mathrm{m})\end{array}$ & $\begin{array}{c}\text { Lowest } \\
\text { Elevation }(\mathrm{m})\end{array}$ \\
\hline 1 & Abu-Talha & 9227 & 13984.2 & 45.40 & 442 & 6 \\
\hline 2 & Aqrawy & 10882 & 15475.2 & 68.84 & 353 & 14 \\
\hline 3 & Awij & 21215 & 14882.7 & 50.76 & 598 & 7 \\
\hline 4 & Hussob & 4268 & 16082.1 & 50.33 & 398 & 28 \\
\hline 5 & Hwaimy & 40340 & 14787.4 & 46.65 & 807 & 11 \\
\hline 6 & Al-Khur & 48840 & 6399 & 49.78 & 912 & 56 \\
\hline 7 & Rhaimay & 3664 & 436 & 43.19 & 381 & 30 \\
\hline 8 & Taqtaq & 1748 & 259 & 22.13 & 328 & 33 \\
\hline
\end{tabular}

\section{Top Soil Properties}

The source of the rock fragments that make up the soil is a parent material, which might be either bedrock or loose sediments transported from elsewhere by water, wind, or ice. Slope and drainage are the main features of topography that influence soil characteristics. The soil is composed of many particles of various sizes, mostly gravel, sand, silt, and clay. Water infiltrates into soil are large due to rainfall percolation beside some of water that comes from upward by capillary action. The arid and semi-arid areas reflect the warm weather season that causes an increased evapotranspiration, which diminishes soil water supply [8].

According to the United State Soil Taxonomy's classification [9], the Soil in the studied area is classed as aridisols (Dry Soil). It is correlated with desert and semi-desert areas. The soil is typified by thin profile that is sandy and lacking in organic matters, which is associated with a dry climate and scarcity of moisture.

The top soil can be classified according to another classification [10] as a Clacisol CL, whereas it was classified elsewhere as Calcic Yermosols [11]. The top soil's thickness in the studied area was about $0.3-1$ meters. The top soil texture is medium, where the drainage class $(0-0.5 \%)$ is moderately well, which is attributed to its location within high latitudes. According to the United State Department of Agriculture's soil textural classification, the dominant soil class in the studied area is clayey loam (Sand fraction 39\%, Silt fraction 37\%, and Clay fraction 24\%), whereas the gypsum weight ratio was 0.1 , the gravel content ratio was $20 \%$, and the calcium carbonate weight ratio is 26 $\%$. In fact, most of the top soil in the studied area is thin, especially in the western part where it does not exceed $(30 \mathrm{~cm})$ of depth and the exposed rock beds are common due to erosion actions (Figure$11)$. 


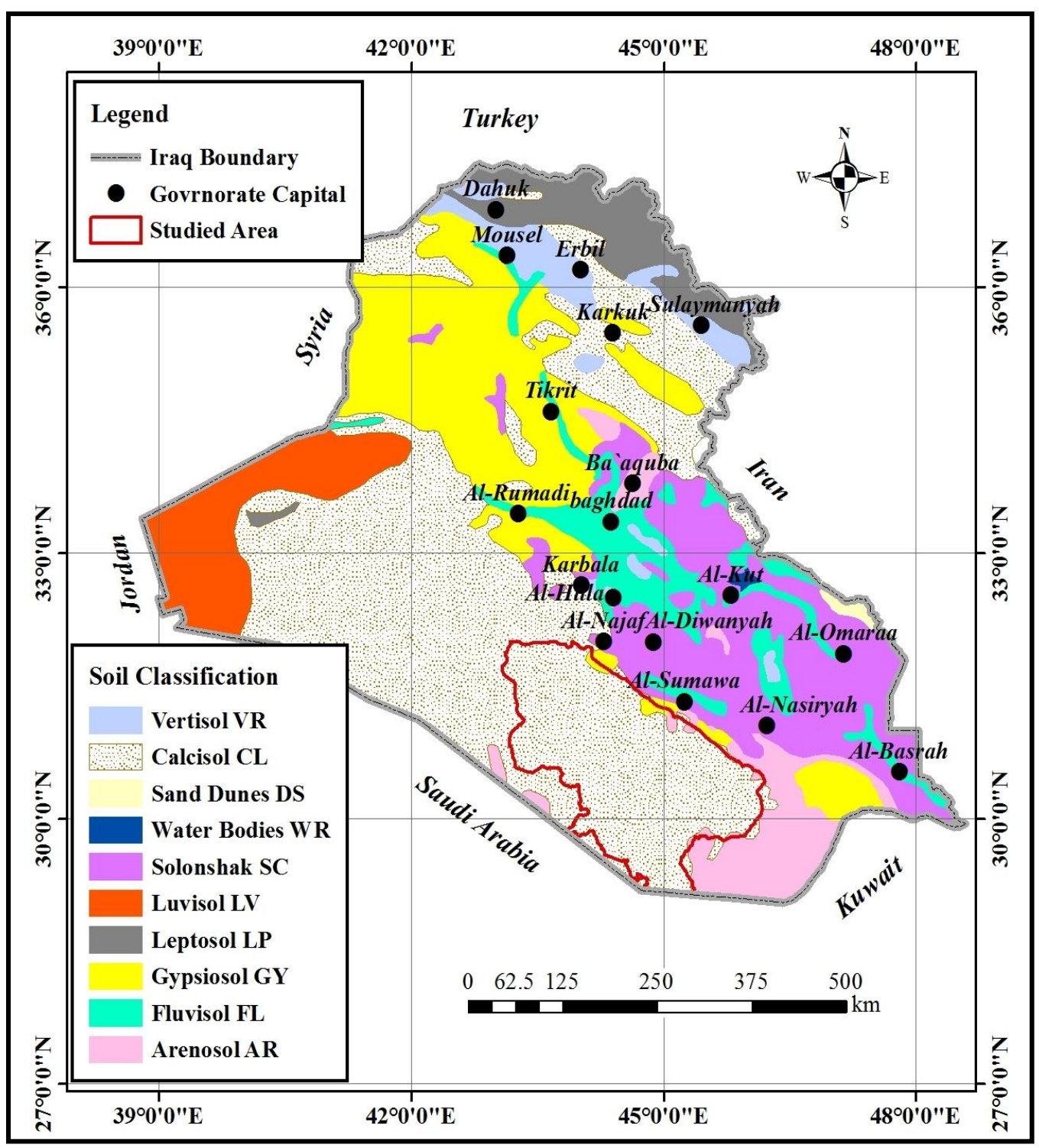

Figure 11- Iraq Soil Map Distribution (HWSD, 2012).

The moisture is added to the soil by percolation of rainfall, but is diminished largely through evapotranspiration. The dynamic relationship between soil and water refers to the soil - water balance, which is determined by temperature and humidity. The field capacity (Available Water Capacity; AWC) means that most of the pore spaces are filled with water [8]. According to an earlier report [10], the soil AWC (Moisture Deficit) in the studied area was $15 \mathrm{~mm}$, while the top soil saturation was 100 $\%$.

\section{The Climate}

The climatic daily values were provided from the General Commission of Meteorological and Seismic Monitoring of Al-Najaf and Al-Muthanna governorates for the last 11 years (2008-2018) [12]. The annual yearly rainfall is $135.6 \mathrm{~mm}$, the average annual temperature was $25.6 \mathrm{C}^{\mathrm{o}}$, the total depth amount of E Apan was $2976.6 \mathrm{~mm} / \mathrm{year}$, the relative humidity was $41 \%$, the average annual sunshine was 7.5 hrs., and the average annual wind speed was $1.6 \mathrm{~m} / \mathrm{s}$ for Al-Najaf. While the annual rainfall was $131.61 \mathrm{~mm}$, the average annual temperature was $25.9 \mathrm{C}^{\circ}$, the total depth amount of E Apan was $4407.1 \mathrm{~mm} /$ year, the relative humidity was $37 \%$, the average annual sunshine was $8.3 \mathrm{hrs}$. , and the average annual wind speed was $3.3 \mathrm{~m} / \mathrm{s}$ for Al-Muthanna. The calculated average values of the total studied area show that the average annual rainfall was $133.11 \mathrm{~mm}$, the average annual temperature was $25.65 \mathrm{C}^{0}$, the total depth amount of (E Apan)was $3691.85 \mathrm{~mm} /$ year, the relative humidity was 40 $\%$, the average annual sunshine was 7.9 hrs., and the average annual wind speed was $2.7 \mathrm{~m} / \mathrm{s}$, (Table$3)$.

Table 3- The Climatic Values of the Monthly Averages in Studied Area. 


\begin{tabular}{|c|c|c|c|c|c|c|}
\hline Months & $\begin{array}{c}\text { Temp. } \\
\left(\mathbf{C}^{\circ}\right)\end{array}$ & $\begin{array}{c}\text { Rainfall } \\
(\mathbf{m m})\end{array}$ & EApan $(\mathbf{m m})$ & $\begin{array}{c}\text { Relative } \\
\text { Humidity(\%) }\end{array}$ & $\begin{array}{c}\text { Sunshine } \\
(\mathbf{h o u r s})\end{array}$ & $\begin{array}{c}\text { Wind } \\
\text { speed } \\
(\mathbf{m} / \mathbf{s})\end{array}$ \\
\hline Oct. & 27.5 & 12.9 & 273.9 & 39 & 6.9 & 2.1 \\
\hline Nov. & 18.5 & 36.5 & 127.3 & 57 & 5.9 & 1.8 \\
\hline Dec. & 13.6 & 16.05 & 87.3 & 60 & 5.7 & 2 \\
\hline Jan. & 11.8 & 16.46 & 87.5 & 62 & 5.8 & 2.2 \\
\hline Feb. & 14.6 & 11.66 & 122.75 & 53 & 6.7 & 2.4 \\
\hline Mar. & 20.6 & 12.25 & 217.1 & 42 & 7.7 & 2.4 \\
\hline Apr. & 28.8 & 15.7 & 253 & 36 & 7.6 & 2.6 \\
\hline May & 28.9 & 11.59 & 413.75 & 29 & 8.0 & 5.8 \\
\hline Jun. & 36.3 & 0 & 532.85 & 23 & 10.1 & 3.2 \\
\hline Jul. & 38.4 & 0 & 600.45 & 22 & 10.6 & 3.1 \\
\hline Aug. & 37.7 & 0 & 568.9 & 24 & 10.4 & 2.8 \\
\hline Sep. & 34 & 0 & 407.05 & 27 & 9.2 & 2.1 \\
\hline Average & 25.9 & $(133.11) \sum$ & $\sum(3691.85)$ & $40 \%$ & 7.9 & 2.7 \\
\hline
\end{tabular}

\section{Potential Evapotranspiration (PE)}

Potential evapotranspiration (PE) is defined as the maximum rate of evapotranspiration under prevailing meteorological conditions over short-rooted vegetation with limitless water supply [13]. When the evapotranspiration is reduced then the runoff and the groundwater infiltration increase. The heat from pavement areas cause overlying air to warm and rise which can increase the evapotranspiration from the vegetated area [14]. The term potential evapotranspiration was defined by Thornthwait (1948) as "the water loss which will occur if at any time there is a deficiency of water in the soil for the use of vegetation $[14,15]$. Actual evapotranspiration can be defined as the real amount of evaporation and transpiration of the surface under climatic factors [16].

The actual water evaporation is very important to initiate the factors of water balance in the studied area, which are used to determine the amount of drainage and the amount of storage in the Dammam unconfined aquifer.

The calculation of the consumptive use of the crops on the basis of the mean daily temperature, latitude of the zone, and month of the year was developed by Thornthwiate (1948) [17].

The PE value can be calculated as below:

$$
\begin{aligned}
& \mathrm{PE}=16[10 \mathrm{tn} / \mathrm{J}]^{\mathrm{a}} \mathrm{mm} / \text { month } \\
& \mathrm{J}=\sum_{j=1}^{12} j \text { for the } 12 \text { month } \\
& \mathrm{j}=[\operatorname{tn} / 5]^{1.514}
\end{aligned}
$$

where:

$\mathrm{PE}=$ Potential evapotranspiration for each month ( $\mathrm{mm} /$ month).

$\mathrm{t}=$ Daily month mean air temperature $\left(\mathrm{C}^{\circ}\right)$.

$\mathrm{n}=$ Number of monthly measurements.

$\mathrm{J}=$ Annual heat index $\left(\mathrm{C}^{\circ}\right)$.

$\mathrm{j}=$ Daily month temperature parameter $\left(\mathrm{C}^{\circ}\right)$.

$\mathrm{a}=$ Constant.

$\mathrm{a}=\left(675 \times 10^{-9}\right) \mathrm{J}^{3}-\left(771 \times 10^{-7}\right) \mathrm{J}^{2}+\left(179 \times 10^{-4}\right) \mathrm{J}+0.492$

The value of (a) is equal to (3.81).

Moreover, the values of the corrected potential evapotranspiration (PEc) can be determined from the following equation [14]:

$$
\mathrm{PEc}=\mathrm{PE} \times \frac{D T}{360}
$$

where: 
PEc : Corrected potential evapotranspiration(mm).

$\mathrm{PE}$ : potential evapotranspiration $(\mathrm{mm})$.

D: number of days in the month.

T: average number of hours between sunrise and sunset in the month.

The corrected potential evapotranspiration values are high during the months of April to October while they are low during the months of November to March. This variation is related to seasonal changes, where summer and winter are long whereas spring and autumn are short (Table- 4).

Table 4- Potential evaporation-transpiration values calculated for the period of 2008-2018 using Thornthwaite (1948) method.

\begin{tabular}{|c|c|c|c|c|c|c|}
\hline Months & Temp. $\left(\mathrm{C}^{\mathrm{o}}\right)$ & $\mathrm{j}\left(\mathrm{C}^{\mathrm{o}}\right)$ & $\mathrm{DT} / 360$ & $\mathrm{PE}(\mathrm{mm})$ & Epan $(\mathrm{mm})$ & PEc $(\mathrm{mm})$ \\
\hline Oct. & 27.5 & 13.2 & 0.59 & 152 & 273.9 & 89.6 \\
\hline Nov. & 18.5 & 7.2 & 0.49 & 33.5 & 127.3 & 16.4 \\
\hline Dec. & 13.6 & 4.5 & 0.49 & 10.4 & 87.3 & 5.1 \\
\hline Jan. & 11.8 & 3.6 & 0.49 & 6.1 & 87.5 & 2.9 \\
\hline Feb. & 14.6 & 5.1 & 0.54 & 13.6 & 122.75 & 7.3 \\
\hline Mar. & 20.6 & 8.5 & 0.66 & 50.6 & 217.1 & 33.4 \\
\hline Apr. & 28.8 & 14.1 & 0.36 & 181.3 & 253 & 114.2 \\
\hline May & 28.9 & 14.2 & 0.69 & 183.7 & 413.75 & 126.5 \\
\hline Jun. & 36.3 & 20.11 & 0.84 & 437.8 & 532.85 & 367.8 \\
\hline Jul. & 38.4 & 21.8 & 0.91 & 542.4 & 600.45 & 493.6 \\
\hline Aug. & 37.7 & 21.2 & 0.89 & 505.7 & 568.9 & 450.1 \\
\hline Sep. & 34 & 18.2 & 0.76 & 341.2 & 407.05 & 259.3 \\
\hline & & $\mathrm{J}=152.3$ & & 2458.3 & 3691.9 & 1966.2 \\
\hline
\end{tabular}

The values of potential evapotranspiration were calculated according to equation (1) and corrected according to equation (4). These two equations were applied by Thornthwaite (1948) and are daily month temperature dependent. According to the values of evaporation, PE, and PEc a relation was drawn (Figure- 12).

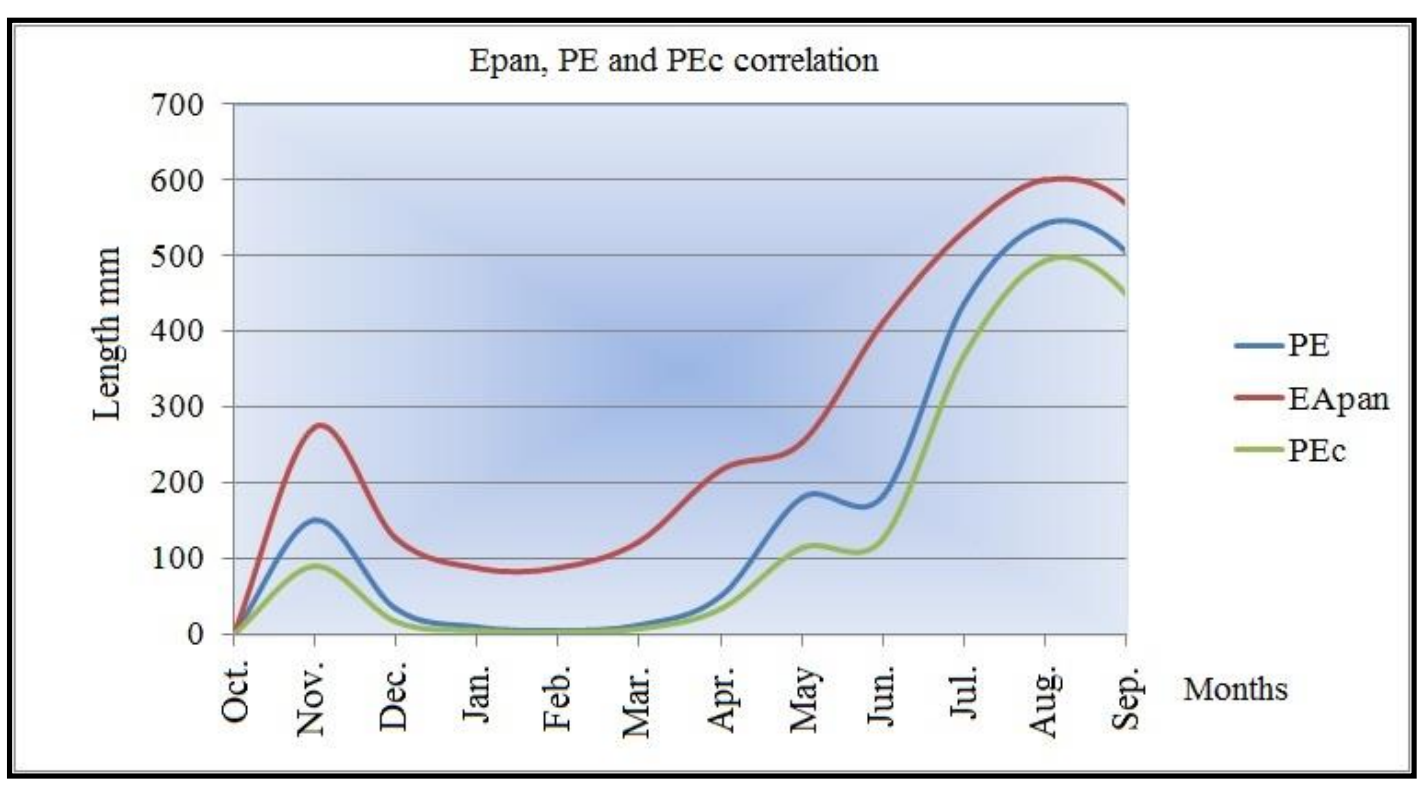

Figure 12- Epan, PE and PEc correlation graph

\section{Water Surplus (WS) and Water Deficit (WD)}

Water always takes the path of least resistance surface, flowing downhill from higher to lower elevations, eventually reaching a river or its tributaries. All of the land that eventually drains to stream 
is considered to be in the same watershed or runoff zone. The steeper land gradient and the less porous soil make a greater runoff. Understanding the factors that affect the rate and direction of surface and water infiltration helps to determine WS and WD [18].

Water surplus is defined as the excess of rainfall that exceeds the corrected potential evapotranspiration values during specific months of the year, while water deficit is the amount of corrected potential evapotranspiration values exceeding the amount of rainfall during the remaining months of that year [19].

The corrected water balance takes in consideration all the parameters, such as soil moisture, runoff, and groundwater recharge. Determination of the water surplus and water deficit was achieved according to the correlation between precipitation PEc (Figure- 13)

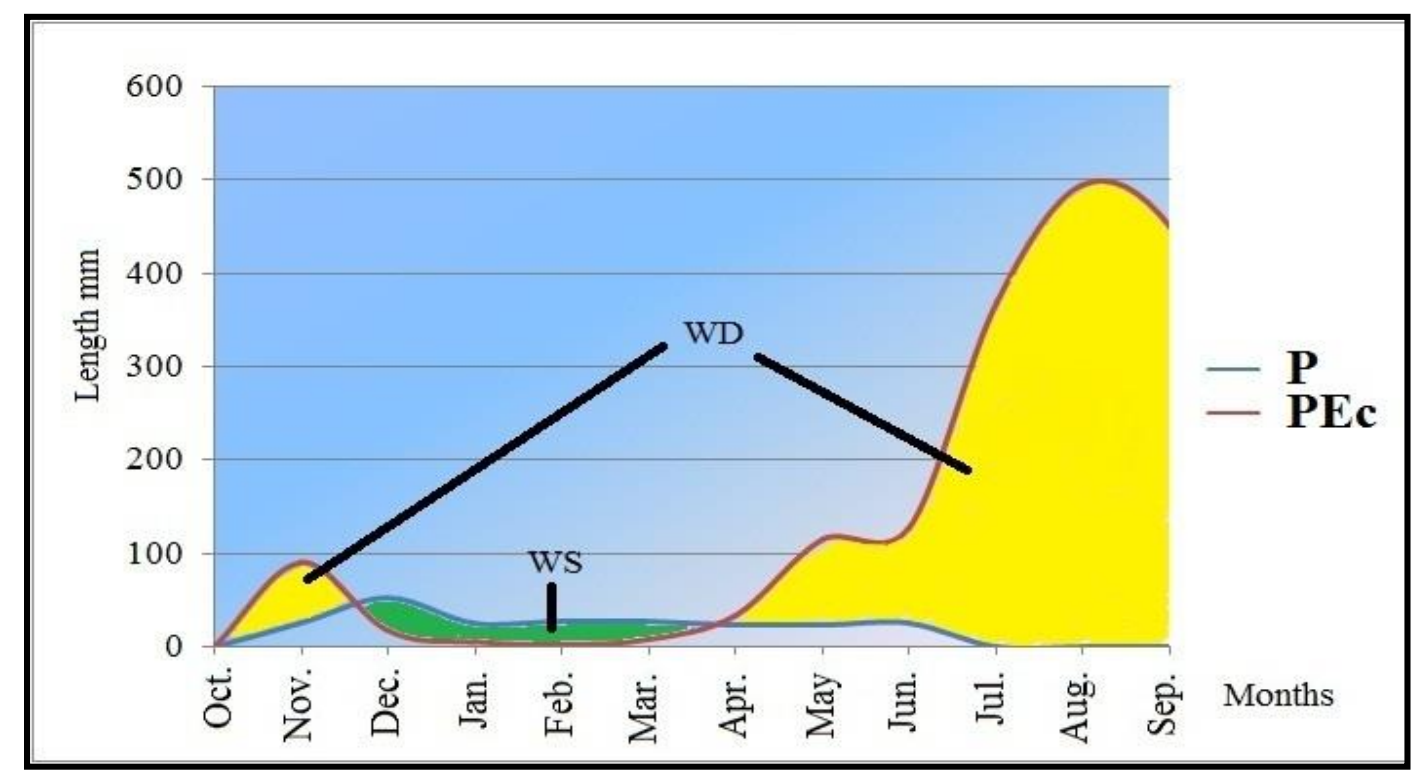

Figure 13- $\mathrm{P}$ and $\mathrm{PEc}$ correlation graph

The green area in Figure-13 represents the amount of excess rainfall, while the yellow area represents the amount of corrected potential evapotranspiration values during the year. The PE value can be derived as follows:

$$
\begin{array}{ll}
\mathrm{PE}=\mathrm{PEc} & \text { when } \mathrm{P} \geq \mathrm{PEc} \\
\mathrm{PE}=\mathrm{P} & \text { when } \mathrm{P}<\mathrm{PEc}
\end{array}
$$

According to the first equation, potential evapotranspiration is equal to the corrected potential evapotranspiration, whereas in the second equation it is equal to rainfall values as shows in the following:

$$
\begin{aligned}
& \mathrm{WS}=\mathrm{P}-\mathrm{PEc} ; \mathrm{P}>\mathrm{PEc} \quad \mathrm{PEc}=\mathrm{PE} \\
& \mathrm{WD}=\mathrm{PEc}-\mathrm{P} ; \mathrm{P}<\mathrm{PEc} \quad \mathrm{P}=\mathrm{PE}
\end{aligned}
$$

In addition to the presence of appreciable wet soil due to rainfall or to irrigation, actual evapotranspiration value was complemented by an amount from the AWC in the soil, reaching at some times to the value of potential evapotranspiration; otherwise it remains less than the potential evapotranspiration.

Soil moisture content is defined as the water that could be evaporated from soil by heating at $105^{\circ} \mathrm{C}$ for a constant weight. The choice of the temperature limit is arbitrary, and clayey soils retain a considerable quantity of water at this temperature. Water in the soil is held by the forces of cohesion and adhesion, in which surface tension, capillarity pressure, and osmotic pressure play a significant role [20].

When a fully saturated soil is allowed to drain freely under the force of gravity and there is no loss due to evaporation, the soil's moisture content will approach an equilibrium level. This equilibrium in soil's moisture content is called AWC (Moisture Deficit). 
According to that, the soil moisture (SM) of the top soil in the studied area is (15 mm) instead of 100 $\mathrm{mm}$, due to the thin soil in the studied area and the fact that runoff is expected in the rainy time. Therefore, equations 8 and 9 will be as follow:

$$
\begin{gathered}
-\mathrm{WS}=\mathrm{P}-\mathrm{PEc}-\mathrm{SM} ; \mathrm{P}>\mathrm{PEc} \quad \mathrm{PEc}=\mathrm{PE} \\
-\mathrm{WD}=\mathrm{PEc}+\mathrm{SM}-\mathrm{P} ; \mathrm{P}<\mathrm{PEc} \quad \mathrm{P}=\mathrm{PE}
\end{gathered}
$$

The mean values of monthly water surplus and water deficit are shown in (Table -5$)$.

Table 5- Calculated monthly averages of water surplus and water deficit for the studied area.

\begin{tabular}{|c|c|c|c|c|}
\hline Month & $\mathbf{P}(\mathbf{m m})$ & $\mathbf{P E c}(\mathbf{m m})$ & $\mathbf{W s}(\mathbf{P}-\mathbf{P E c}-\mathbf{S M})(\mathbf{m m})$ & $\mathbf{W D}(\mathbf{P E c}+\mathbf{S M - P})(\mathbf{m m})$ \\
\hline Oct. & 12.9 & 89.6 & 0 & 91.7 \\
\hline Nov. & 36.5 & 16.4 & 5.1 & - \\
\hline Dec. & 16.05 & 5.1 & 0 & 4.05 \\
\hline Jan. & 16.46 & 2.9 & 0 & 1.44 \\
\hline Feb. & 11.66 & 7.3 & 0 & 10.64 \\
\hline Mar. & 12.25 & 33.4 & 0 & 36.15 \\
\hline Apr. & 15.7 & 114.2 & 0 & 113.5 \\
\hline May & 11.59 & 126.5 & 0 & 129.91 \\
\hline Jun. & 0 & 367.8 & - & 382.8 \\
\hline Jul. & 0 & 493.6 & - & 508.6 \\
\hline Aug. & 0 & 450.1 & - & 465.1 \\
\hline Sep. & 0 & 259.3 & - & 274.3 \\
\hline $\boldsymbol{\Sigma}$ & 121.99 & 1966.2 & 5.1 & 2018.19 \\
\hline
\end{tabular}

The yearly amount of water surplus calculated from the equation 10 is represented as runoff and ground infiltration (groundwater recharge). The water surplus in November was $5.1 \mathrm{~mm}$, when $\mathrm{P}$ exceeds PEc and AWC, while the period from December to October is considered as water deficit, when PEc and AWC exceed P was $2018.19 \mathrm{~mm}$. The groundwater (GW) recharge and the surface runoff (SR) are coming from outside the studied area and infiltrated through soil. The drainage pattern of the streams network can be used to determine the amount of the runoff, especially to the transboundary basins.

According to a previous study [7], the expected ratio of the average runoff ranges 12.72-3.86\% from yearly rain fall. Therefore the mean average was $8.29 \%$ from the water surplus. The yearly runoff was $0.422 \mathrm{~mm}$ for each basin in the studied area. The volume of yearly runoff is determined by multiplying the yearly runoff by the basin area, which is shown in (Table- 6 ).

\begin{tabular}{|c|c|c|c|}
\hline No & Name & Basin Area $\left(\mathrm{km}^{2}\right)$ & $\begin{array}{c}\text { Yearly Runoff volume } \\
\text { Million }\left(\mathrm{m}^{3}\right)\end{array}$ \\
\hline 1 & Abu-Talha & 9227 & 3.893 \\
\hline 2 & Aqrawy & 10882 & 4.592 \\
\hline 3 & Awij & 21215 & 8.952 \\
\hline 4 & Hussob & 4268 & 1.801 \\
\hline 5 & Hwaimy & 40340 & 17.023 \\
\hline 6 & Al-Khur & 48840 & 20.610 \\
\hline 7 & Rhaimay & 3664 & 1.546 \\
\hline 8 & Taqtaq & 1748 & 0.737 \\
\hline \multicolumn{2}{|c|}{$\sum$} & 140184 & 60.7 \\
\hline
\end{tabular}

Table 6- Yearly Expected Runoff in the Studied Area. 


\section{Conclusions}

The calculated average monthly evaporation (EApan) in the studied area was $3691.9 \mathrm{~mm}$ and the potential evapotranspiration was $2458.3 \mathrm{~mm}$, while the corrected potential evapotranspiration was $1966.2 \mathrm{~mm}$, where the values are related as follows: Epan > PE > PEc.

The total volume amount of water surplus can be determined by multiplying the water surplus (5.1 $\mathrm{mm}$ ) by the total area of the studied area $\left(46800 \mathrm{~km}^{2}\right)$, which was about $488.592 \mathrm{M} \mathrm{m}^{3} / y e a r$.

The total amount of infiltrated groundwater (recharge) is determined by subtracting the runoff amount from total volume value, which was about $442.190 \mathrm{M} \mathrm{m}^{3}$ /year. This amount is recharging all aquifers within the studied area, not only the Dammam aquifer but also the Umm-Er-Rhdumma and the Tayarat aquifers.

\section{References}

1. Jassim, S.Z. and Goff, J.C. 2006. Geology of Iraq, Pub., Doline, First edition,341p.

2. Al-Dabbas and Hussain, 2018. Climatic Water Balance in AL-Amaid Area/ Muthana Governorate/ Southwest Iraq, Iraqi Journal of Science, 59(2B): 865-874 DOI:10.24996 /ijs. 2018 .59.2B.7.

3. Al-Sudani 2018. Calculating of Groundwater Recharge using Meteorological Water Balance and Water level Fluctuation in Khan Al-Baghdadi Area , Iraqi Journal of Science, 59(1B): 349-359 DOI: 10.24996/ijs.2018.59.1B.13.

4. Lyon, J.G. 2003. GIS for Water Resources and Watershed Management, British Library, UK, $266 \mathrm{p}$.

5. Karanth K.R. 2008. Groundwater Assessment Development and Management, Tata McGraw-Hill Offices, NEW DELHI.P.720.

6. Tamar Agha M.Y. 1983. Hydrogeological and Hydrotechnical Exploration in Blocks 1, 2, 3. Final report on Geology of the southern Desert Vol. No. 3 GEOSURV Library Report No. 1424.

7. ACSAD, 2013. Evaluation of water resources in groundwater and surface water report 2013Baruit Labnon p100.

8. McKnight, T.L. and Hess, D. 2008. Physical Geography A Landscape Appreciation, Ninth edition, New Jersey, USA, 611p.

9. Nyle C. Brady and Ray R. Weil, 1999. The nature and properties of soil, $15^{\text {th }}$ ed., Person Education, Inc.India,881p.

10. HWSD-FAO, 2012. Food and Agriculture Organization of the United Nation, Irrigation and Drainage, Rome.

11. FAO, 1974: Food and Agriculture Organization of the United Nation, Irrigation and Drainage, Rome.

12. Iraqi meteorological organization, 2018. Climatic elements data of recorded in Al-Najaf station and Sammwa station for period from (2008-2018).

13. Hiscock, K.M. 2005. Hydrogeology Principles and Practice, University of East Anglia, UK, $389 \mathrm{p}$.

14. Todd, D.K. 2007. Groundwater hydrology, $3^{\text {th }}$ ed, Jhon Wiley and Sous, Third Reprint. Inc. India. $535 \mathrm{p}$.

15. Viessman, W.J. and Lewis, G.L. 2007. Introduction to Hydrology, $5^{\text {th }}$ ed., Person Education, Inc.and Dorling Kindcrsly,Inc.India,612p.

16. Brickle, P., Rodrigues, V.T., Partida, E.G. 1995. Effects of evapotranspiration of the water balance of the valley of Mexico. Geofisica Int. 35(1): 63-72.

17. Wilson, E.M. 1971. Engineering hydrology, McGraw-Hill Press. Ltd. 182p.

18. Bedient, P.B., Huber, W.C., Vieux, B.E. 2008. Hydrology and Floodplain Analysis, $4^{\text {th }}$ ed, Prentic-Hall, Inc, USA, New Jersey, 795p.

19. Lerner, N. D., Issar, A. S. and Simmers, I. 1990. Groundwater Recharge-A Guide to Understanding and Estimating Natural Recharge, Vol.8, Association of Hydrogeologist, Hanover, ISBN 3-922705-91-X.

20. Dekker, H.C. 2004. Control of inter-organizational relationships: evidence on appropriation concerns and coordination requirements. Accounting, Organizations and Society, 29(1): 27-49. 